\title{
How Does the European Recovery Target for Construction \& Demolition Waste Affect Resource Management?
}

\author{
Maria Arm $^{1}$ • Ola Wik ${ }^{1}$ - Christian J. Engelsen ${ }^{2}$ - Martin Erlandsson ${ }^{3,4}$. \\ Ole Hjelmar ${ }^{5}$ Margareta Wahlström ${ }^{6}$
}

Received: 18 March 2016/Accepted: 16 August 2016/Published online: 6 September 2016

(c) The Author(s) 2016. This article is published with open access at Springerlink.com

\begin{abstract}
The revised EU Waste Framework Directive (WFD) includes a $70 \%$ target for recovery of construction and demolition (C\&D) waste. In order to study the potential change in the resource management of the main $C \& D$ waste fractions, as a consequence of fulfilling the WFD target, a Nordic project (ENCORT-CDW) has been performed. Waste fractions studied included asphalt, concrete, bricks, track ballast, gypsum-based construction materials and wood. Recovery scenarios were identified and estimations were made regarding expected savings of primary materials, impact on transport, and pollution and emissions. For wood waste, the main differences between re-use, material recycling and energy recovery were evaluated in a carbon footprint screening based on life cycle assessment methodology. The study concluded that the EU recovery target does not ensure a resource efficient and environmentally sustainable waste recovery in its present form since:
\end{abstract}

Maria Arm

maria.arm@swedgeo.se

1 Swedish Geotechnical Institute SGI, 58193 Linköping, Sweden

2 Byggforsk, SINTEF, P.O. Box 124, Blindern, 0314 Oslo, Norway

3 IVL Swedish Environmental Research Institute Ltd, Valhallavägen 81, 11427 Stockholm, Sweden

4 KTH Royal Institute of Technology, School of Architecture and the Built Environment, 10044 Stockholm, Sweden

5 Danish Waste Solutions ApS, Agern Allé 3, 2970 Hørsholm, Denmark

6 VTT Technical Research Centre of Finland Ltd, P.O. Box 1000, 02044 VTT, Finland
- It is very sensitive to how the legal definitions of waste and recovery are interpreted in the Member States. This means that certain construction material cycles might not count in the implementation reports while other, less efficient and environmentally safe, recovery processes of the same material will count.

- It is weight-based and consequently favours large and heavy waste streams. The result is that smaller flows with equal or larger resource efficiency and environmental benefit will be insignificant for reaching the target.

- It does not distinguish between the various recovery processes, meaning that resource efficient and environmentally safe recovery cannot be given priority.

Improved knowledge on $\mathrm{C} \& \mathrm{D}$ waste generation and handling, as well as on content and emissions of dangerous substances, is required to achieve a sustainable recovery.

Keywords Recovery - Construction \& demolition waste . Life cycle assessment $\cdot$ Resource efficiency

\section{Introduction}

The revised framework for waste management in the EU (WFD) [1] which was adopted in 2008 includes a target for recovery of construction and demolition waste (C\&D waste) which reads

"by 2020, the preparing for re-use, recycling and other material recovery, including backfilling operations using waste to substitute other materials, of nonhazardous construction and demolition waste excluding naturally occurring material defined in category 170504 in the list of waste shall be increased to a minimum of $70 \%$ by weight." 
The recovery target was added during the final negotiations of the Directive text and rules for verifying compliance was established in 2011 [2]. The rules ${ }^{1}$ specify 27 waste codes, which are covered by the target. The codes are derived from European Waste Codes (EWC) in the European List of waste [3]. As an example, no waste containing dangerous substances is included. Furthermore, the only type of "soil" 2 covered by the target is track ballast not containing dangerous substances. The rules for verifying compliance also include the calculation method that Member States should use for implementation reports. It reads

Recovery rate of construction and demolition waste; in \%

$$
=\frac{\text { Materially recovered amount of } \mathrm{C} \& \mathrm{D} \text { waste }}{\text { Total amount of generated } \mathrm{C} \& \mathrm{D} \text { waste }}
$$

An evaluation of the impact of the target is planned by the European Commission and in order to provide some of the basis for this evaluation, the Swedish Environmental Protection Agency (SEPA) initiated a Nordic project, ENCORT-CDW, which was reported in spring 2014 [4]. The objective of the project was to study the potential change in the resource management of the main C\&D waste fractions as a consequence of fulfilling the WFD target. This paper presents the main findings of the ENCORT-CDW project, supplemented with new data. For new data, the data source is indicated in the list of references, in other cases the reader is referred to the ENCORTCDW report [4]. The Nordic countries included in this study were Denmark, Finland, Norway and Sweden.

\section{Waste Fractions Studied and Project Methodology}

\section{Waste Fractions Studied}

Based on the specified 27 waste codes in the rules for reporting compliance with the recovery target, the following waste types were selected for further study in the ENCORT-CDW project:

- Concrete (EWC 170101)

- Bricks, tiles \& ceramics and mixtures of these and concrete (EWC 170102-170103, 170107)

- Wood (EWC 170201)

- Bituminous mixtures not containing coal tar (EWC 170302)

- Track ballast (EWC 170508)

- Gypsum-based construction materials (EWC 170802)

\footnotetext{
${ }^{1}$ Which are given in annex III of Decision 2011/753/EU [2].

${ }^{2}$ Excavated track ballast, with EWC 170508, is listed in subchapter 1705 "Soil (including excavated soil from contaminated sites)stones and dredging spoil" in the European List of wastes [3].
}

The selection was made to represent large and heavy waste streams of importance to fulfil the WFD target, which is weight-based. No glass, plastic, metals or insulation materials were studied and neither were wastes from the mechanical treatment of $C \& D$ waste. Furthermore, no mixed wastes other than mixtures of concrete, bricks, tiles and ceramics were included in the study.

\section{Methodology}

According to the prerequisites for the study, the recovery operations pointed out in the EC target were evaluated, i.e. re-use, recycling and other material recovery excluding energy recovery. However, at the request of SEPA, energy recovery of wood waste was also evaluated. The study used the WFD definitions of C\&D waste, re-use, recovery, material recovery, recycling and backfilling. Only impacts regarding transport, resource management and spreading of pollutants were studied. A screening LCA was made for wood waste, whereas a "life cycle perspective" (a service life of 100 years) was used for the other waste types studied.

A scenario-based approach was chosen for the study. This was due to ambiguities in how to apply the definition of waste, which in parts has led to shortcomings in the current statistics, and therefore considerable uncertainty regarding the material types and quantities that should be covered to meet the WFD recovery target.

Recovery scenarios were identified and estimations were made regarding expected savings of primary materials, impact on transport as well as pollution and emissions. The savings in primary materials (by replacing them with waste material) were quantified using an appropriate functional unit. A scenario without waste recycling was described including a quantification of the consumption of material resources such management entails. The impact on transport was estimated for each scenario. This could be done in several ways and some alternatives are shown in the project report [4]. The assessment focused on the relative changes, and for asphalt and concrete the cumulative sum of all transport distances for sub-processes associated with the scenario was calculated.

Information about the pollution content of the various wastes and emission scenarios, describing the spreading of pollutants to air, land and water in connection with various recovery scenarios, was compiled. Here, a "life cycle perspective" was applied, which included future use of the waste through renewed recovery. A scenario without waste recycling was described including the spreading of pollutants that would occur from conventional virginal construction products. Spreading of pollutants from different scenarios was calculated for a selected number of substances and normalized to an appropriate functional unit. 
Finally, comparison between recovery scenarios and the landfill scenario was made.

Information was retrieved from databases (Eurostat and national statistics), literature and personal contacts. In those cases where relevant data were lacking, a qualitative evaluation was done.

For wood waste, the main differences between material recycling and energy recovery were evaluated by performing a screening LCA on climate impact.

A detailed description of the methodology is included in the project report [4].

\section{Results and Discussion}

Estimates of the generation and recovery of C\&D waste and secondary surplus materials in the Nordic construction sector are presented in Table 1 together with numbers on primary production of some materials. The data confirm that the materials studied in the ENCORT-CDW project represent major waste and material flows in relation to the existing rules for evaluating the recovery target for $C \& D$ waste.

It was noted in the study that European statistics on $C \& D$ waste show very large variation between years and between countries [5]. Furthermore, the waste amounts reported for the Nordic countries are not comparable due to different approaches in the data collection. In Denmark, all waste operators have to report the waste generated, whereas in Finland and Sweden, the waste received at treatment facilities is recorded. In Norway, the waste amounts are based on the use of waste factors, which are frequently updated from field surveys. Furthermore, mineral waste contains different material streams and statistics do not distinguish between high quality concrete waste from selective demolition and mixed mineral waste partly unsuitable for recycling. Moreover, the Eurostat data on treatment and recovery do not give information about treatment of waste generated in the construction sector (with exception for mineral waste). This clearly indicates that the numbers are fraught with uncertainties due to different application of the waste definition, but also a very uncertain database.

When various recovery scenarios were compared in terms of resource management and spreading of pollutants, lack of data on material properties raised difficulties for the comparisons. It was concluded that in order to report progress towards a sustainable and safe recycling of waste and surplus material, an improvement of the statistics on the generation and recycling as well as on pollution content and release is needed. This is further discussed later on in the article.

Although the recycling statistics are uncertain, one can conclude that the present recovery rate of asphalt and track ballast waste is generally well above $70 \%$ in the Nordic countries (Table 1). These materials represent large material flows, but at present, they are generally not included in the Nordic waste statistics. In Finland for example, reclaimed asphalt intended for use on site, is generally not regarded as waste. Furthermore, the track ballast waste is in
Table 1 Estimated amounts of primary production of asphalt and concrete, $C \& D$ waste generation and $C \& D$ waste recovery in the Nordic countries, in Mton/year

\begin{tabular}{lllll}
\hline & $\begin{array}{l}\text { Primary } \\
\text { production }\end{array}$ & $\begin{array}{l}\text { Waste/ Secondary } \\
\text { generation }\end{array}$ & $\begin{array}{l}\text { Material } \\
\text { recovery }\end{array}$ & $\begin{array}{l}\text { Energy } \\
\text { recovery }\end{array}$ \\
\hline Asphalt $^{\mathrm{a}}$ & 23 & 3.6 & 3.4 & \\
Concrete $^{\mathrm{b}}$ & 13 & 3.8 & 2.6 & \\
Track ballast $^{\mathrm{c}}$ & & 1.3 & 1 & 0.7 \\
Wood $^{\mathrm{d}}$ & & 0.8 & 0.1 & \\
Gypsum $^{\mathrm{b}}$ & & 0.4 & - & 0.1 \\
Metal $^{\mathrm{d}}$ & & 0.4 & 0.4 & \\
Plastic $^{\mathrm{d}}$ & & 0.2 & 0.1 & \\
Paper and cardboard $^{\mathrm{d}}$ & & 0.04 & 0.04 & 0.0001 \\
Glass $^{\mathrm{d}}$ & & 0.02 & 0.02 & 0.0001 \\
Rubber $^{\mathrm{d}}$ & & 0.0002 & 0.02 & \\
\hline
\end{tabular}

\footnotetext{
a Based on yearly statistics on the primary production of asphalt and generation of reclaimed asphalt [8]. Calculated average for the years 2011-2014

b Based on [4]

c Calculated from track length statistics [29] and an assumed average track ballast generation of $50 \mathrm{t} / \mathrm{km}$, year

d Based on European waste statistics in 2012 [30]. Waste generation is based on statistics for the construction sector. Recovery is based on average treatment percentages for the specific waste streams. For wood waste about $90 \%$ of energy recovery is assumed (after adjustments of Finnish statistics in [31])
} 
many countries not monitored when used on site in railway embankments. Considering their high re-use or recycling rate, including or excluding these materials will highly influence the opportunities of attaining the WFD target of $70 \%$ recovery.

As expected, re-use or recycling on site reduces transport significantly. However, the reduction will vary among countries or even regions since it depends on available supplies and the resources that are replaced, as well as on distances to recycling facilities. In the Nordic countries, Denmark is different from Sweden, Norway and Finland regarding the resources of high quality aggregates, which are largely imported to Denmark [4].

The consequences for spreading of pollutants will also vary since emissions (leaching, particles etc.) depend on how and where the waste is re-used or recycled. Although the use of many dangerous substances have been phased out in new building products there are still considerable amounts of harmful compounds present in old construction products due to their long lifespan. These need to be considered when recycling the construction waste. An essential prerequisite for recycling is pre-demolition auditing of the construction in question. This should be done in order to detect materials containing hazardous substances that need to be removed prior to a selective demolition. In the selective demolition, the sorting of waste into different material fractions is crucial. Unwanted fractions in the C\&D waste reduce its environmental and technical suitability or hinder its later use. In order to ensure a low risk, there is a need for data from the C\&D waste quality protocols (potentially including testing) covering the whole management chain [6].

\section{Recovery of Bituminous Mixtures (“Asphalt”)}

The recovery of reclaimed asphalt pavements (RA) is well established in the Nordic countries, with a variety of demolition and recovery routines, e.g.:

- Re-use ${ }^{3}$ in new asphalt mixes produced at stationary or mobile asphalt plants.

- Re-use in new surface or binder courses through hot inplace recycling.

- Recycling as aggregate in unbound road layers such as bases and sub-bases or surface layers of gravel roads and parking areas.

- Recovery as unspecified filling material (=backfilling).

\footnotetext{
3 Although not formally fulfilling the WFD definition, the term "reuse" is used here to indicate that high-grade recycling into new asphalt mixtures and bound courses can be regarded as re-use since the RA is used again for the same purpose for which it was conceived and with full recovery of its technical functionality.
}

Recovered asphalt based roofing materials can be recycled into paving asphalt by existing techniques [7]. Even though the amount of asphalt roofing material is small compared to paving asphalt, the bitumen content is not negligible.

The use of RA in production of asphalt pavements is covered by harmonized European standards and national guidelines. In Denmark, Finland and Åland (autonomous region in Finland) there are specific legislations regulating RA recycling in bound or unbound layers. Recycling of RA into new asphalt mixtures and bound courses could be regarded as re-use since the RA is used again for the same purpose for which it was conceived. Recycling into unbound layers, on the contrary, is a material recovery technique where the binder properties of bitumen in the RA raw materials are not fully utilised.

The Eurostat data on RA recovery in the Nordic countries are uncertain because traditionally, RA has not been reported as waste and statistics are not kept regarding the technical quality, contamination or recovery routes. However, the European Asphalt Pavement Association (EAPA) reports European statistics on RA handling [8]. For the Nordic countries, these statistics seem to be based on expert judgement, with the exception for Norway where good quality statistics on RA is kept and reported by a branch organisation [9]. About 3-4 million tonnes of RA are generated in the Nordic countries every year, corresponding to about 10-20\% of the total production of new asphalt mixes (Table 1). In Sweden, Finland and Denmark, re-use of RA as input to new asphalt pavements is the most common operation, while a smaller fraction is recovered as unbound aggregates. In Norway, recycling as aggregate in unbound road layers is the most common practice [8].

The ENCORT-CDW report highlights that in plant recycling of RA, for use in new asphalt pavements, reduces transport only to a limited extent compared with landfilling. This is due to the need for transport in sub-processes associated with the recycling scenario (e.g. transport of added aggregates, filler and additives to the asphalt plant and transport of asphalt mix to the construction site). However, in a Danish scenario (with lack of high quality aggregates), it gives significant reduction of transport because of savings of imported high quality virgin aggregates. Recycling of RA in unbound applications increases transport due to the need for transferring RA forth and back from a processing site prior to recycling, and the need for replacing the bitumen binder (Swedish scenario) and imported high quality aggregates (Danish scenario). Inplace recycling can drastically reduce transport (by about $90 \%$ ), in both bound and unbound applications.

The potential impact on groundwater and surface water of using uncontaminated RA in bound or unbound constructions (e.g. roads, parking areas and bicycle paths) will 
be limited and below the general water quality criteria, provided a few common conditions of use are observed $[10,11]$. The former use of coal tar in asphalt binders however, is a prime environmental and health concern, and bituminous mixtures with very high tar contamination are classified as hazardous waste (EWC 170303*). The use and phase-out of tar differs from country to country, but the use was ended in the mid-seventies of the previous century. Around $15 \%$ of the Swedish asphalt pavements (14-22 million tonnes) are estimated to be markedly tar contaminated although below hazard classification [4], while the numbers are much lower in other Nordic countries (estimations for Norway and Denmark are given in [4] and [10]).

The emission rates of PAH from tar contaminated RA in various recovery routes are presented in Fig. 1. Based on laboratory results, the emission of PAH-16 from recovered, tar contaminated, RA is expected to be proportional to the PAH content of the RA. The emission assessment was performed in a life cycle perspective for a service life of 100 years. Emission pathways for PAH were related to the emission of

- Particles during demolition, storage and surface wear of the pavement by studded tires, the latter being an important route in the Nordic countries.

- PAH in fumes during hot recycling.

- PAH in surface run-off and in percolating water from the construction.

Recycling scenarios, where tar contaminated RA is recycled (bound or unbound) in the surface layer of a road, result in high emissions (40-100 \% of the original PAH-16 content) due to surface wear, leaching in surface run-off and emission in fumes during hot recycling (paved roads) or leaching (gravel roads) [4]. On the contrary, in scenarios where tar contaminated RA is recovered in subsurface constructions, e.g. in bound road bases, unbound road sub-

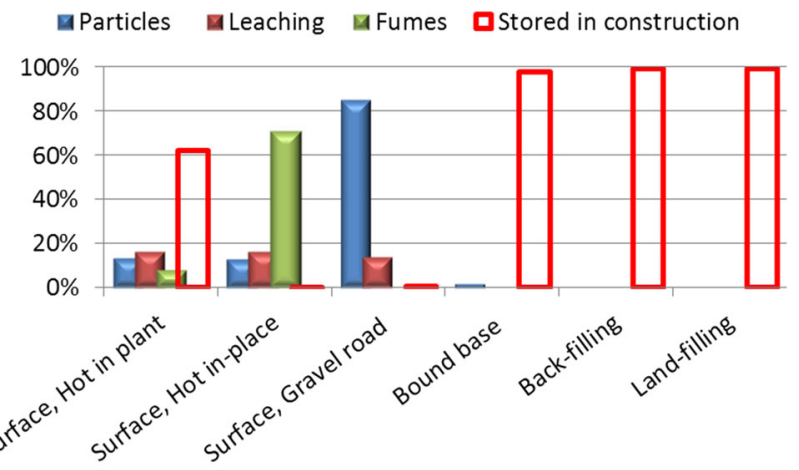

Recycling scenarios

Fig. 1 Emission rates of PAH content in tar contaminated RA, calculated for various recycling scenarios using a life cycle perspective for a service life of 100 years. Data from [4] bases or in backfilling, the emissions will be low (1-2\% of the PAH-16 content). Leaching during temporary storage prior to recovery is the emission process with the lowest impact on the total emissions.

If the existing amount of tar contaminated asphalt in Swedish road binders or base courses would be recycled into surface courses, the diffuse PAH emission could be significantly increased. The uncertainties associated with estimated emissions are large, due to limited data or model descriptions of the emission process. It is noteworthy that the most important emission processes (fumes, particle release and surface run-off) are also the most uncertain processes.

Essentially all PAHs will remain in the subsurface constructions after a service life of 100 years and any environmental or health risk will depend on the future land use. This is the case also for uncontaminated RA where the relatively high content of hydrocarbons can put restrictions on the recycling routes of RA [10].

LCA studies on RA re-use in new asphalt mixes and bound layers have shown that re-use is advantageous compared to the use of primary asphalt, primarily due to the savings of bituminous binder [6, 12]. Recycling by backfilling or recycling into unbound road layers yields significantly less environmental benefits. Cold recycling of contaminated RA into bound base courses would ensure both safe handling and low release of PAH while obtaining the environmental benefits of RA re-use. Current stakeholder guideline values for recovery of RA without restrictions, PAH-16 content of 70-100 mg/kg RA [13], are very high compared to the PAH content in virgin asphalt $(<0.6 \mathrm{mg} / \mathrm{kg} \mathrm{RA})$ [4]. To prevent that tar contaminated RA enters recycling routes with high emission factors the guideline values need to be lowered.

Administrative barriers for processing sites could counteract high-grade recycling, and a simplified regulatory framework (permit system) for RA recycling into bound layers is held to be beneficial from an environmental point of view. To improve the assessment and give recommendations on limit values for use of tar contaminated asphalt, more information is needed regarding generation routes, recycling routes and PAH contents as well as regarding improved data, models and estimations for $\mathrm{PAH}$ emissions.

\section{Recovery of Concrete, Bricks, Tiles and Mortar Waste}

\section{Concrete Rubble}

Concrete waste is recovered largely in the Nordic countries, about 3-4 million tonnes per year, even though statistics are uncertain. Backfilling is the most common 
scenario, while re-use of concrete structures or elements is rare at present. However, re-use may become more relevant in the future if a larger number of buildings are designed for dismantling.

Recovery of concrete often consists of homogenisation and crushing in order to obtain a specific particle size distribution. Selected recovery scenarios evaluated in this study were the use of crushed concrete as

- Aggregate in unbound layers in roads and parking areas, e.g. as sub-base.

- Aggregate in concrete production.

- Final cover material on landfills, e.g. as drainage layer (=backfilling).

- Filling material at the demolition site (=backfilling).

Although the concrete application is considered as highgrade recycling, recycled aggregates from concrete rubble are insignificantly used in the production of ready-mix and precast-element concrete in the Nordic countries. Only in pre-cast element production, the scrap concrete elements are recycled at the factory site and used as raw material for new production. This waste is not regarded as C\&D waste.

When concrete rubble is recycled as road sub-base, a smaller material mass is used due to the lower bulk density of crushed concrete compared to virgin aggregates. Thus, the recycling may save up to $1.2 \mathrm{~kg}$ of primary aggregates per $\mathrm{kg}$ of crushed concrete used. As various primary materials are used for backfilling, e.g. soil, it is difficult to specify the saving of primary materials by weight for this scenario. When recycled concrete aggregate (RCA) is used to produce new concrete, $20-30 \%$ by weight of the primary coarse aggregate is saved per cubic metres concrete produced.

The impact on transport was estimated by assessing and summing the various distances in urban areas between the demolition site, the processing plant, the natural aggregate source and the landfill. It was found that transport decreased in most cases where concrete was recovered.

The exposure pathways used in the emission evaluation were storage, processing, production and a user phase of 100 years for RCA. Leaching to soil and ground water during the user phase was found to be the most relevant exposure pathway. Since the time for storage and processing of concrete waste is normally less than six month, the leaching was considered insignificant, anticipating an annually average rainfall in the range of 700-1500 $\mathrm{mm}$ in the Nordic countries. The dust exposure was also considered to be within health limits, based on earlier field measurements [14]. Furthermore, a lower release of $\mathrm{Cr}, \mathrm{Zn}$ and $\mathrm{SO}_{4}{ }^{2-}$ was found when crushed concrete was applied in a road sub-base compared to the use as landfill drainage layer (Table 2). It can be assumed that the sub-base scenario will also be favourable compared to backfilling at the demolition site. When RCA is used in new concrete, the chemical release is expected to be comparable to that of regular concrete, if the engineering properties are roughly the same.

\section{Mix of Bricks, Tiles, Mortar and Concrete}

Recovery of bricks, tiles and ceramics in the Nordic countries is probably substantially smaller than the recovery of concrete, but statistics are lacking. Undamaged bricks and tiles can be re-used, typically in renovation of old constructions, but the volumes are very small. For reuse of old bricks, a REBRICK-process has been developed in Denmark, where the old bricks are cleaned by vibrational technology, manually sorted and stabled by a robot [15]. At present, the most common recovery scenario is recovery of mixtures of crushed bricks, tiles, ceramics and concrete in unbound low-grade applications or as filling material [4].

There is a lack of data concerning the waste properties and better knowledge is needed to assess this waste stream.

\section{Estimation of Recovery Rate of Concrete and Masonry Waste}

Based on the quantity and quality of available Nordic data, the recovery rate of concrete and masonry waste (C\&M waste) was estimated for Norway. For 2011-2013, estimates used available data from Statistics Norway, while for 2014, estimates were made after contacting the major demolition contractors in Norway.

Table 2 Calculated cumulative release and L/S for crushed concrete used in sub-base and as landfill drainage layer, applying a constant source term. Compacted density used in the calculations was $1850 \mathrm{~kg} / \mathrm{m}^{3}$

\begin{tabular}{llclrr}
\hline Use as & Infiltration rate $(\mathrm{mm} / \mathrm{y})$ & Depth $(\mathrm{mm})$ & Cumulative L/S (L/kg) & & \multicolumn{2}{c}{ Cumulative leaching (mg/kg) } \\
\cline { 3 - 6 } & & & $\mathrm{Cr}$ & 3.9 & $\mathrm{SO}_{4}{ }^{2-}$ \\
\hline Sub-base & 300 & 500 & 10.8 & 7276 & 0.37 \\
Drainage layer & 400 & 1000 & 22 & 7.8 & 14551 \\
\hline
\end{tabular}

\footnotetext{
${ }^{a}$ Highest release is shown for the constant source term concentrations used in the calculations obtained at $\mathrm{L} / \mathrm{S}=0.6$ at $\mathrm{pH} 12.8$ (native), $\mathrm{L} / \mathrm{S}=10$ at $\mathrm{pH} 12.6-12.9$ (native) and $\mathrm{L} / \mathrm{S}=10$ at $\mathrm{pH} 8-10$
} 
Table 3 Generation and estimated recovery rate of concrete and masonry (C\&M) waste in Norway

\begin{tabular}{|c|c|c|c|c|c|c|c|}
\hline \multirow[t]{2}{*}{ Year } & \multicolumn{2}{|c|}{ Generation (1000 tonnes) } & \multicolumn{2}{|c|}{ Recovery (1000 tonnes) ${ }^{\mathrm{a}}$} & \multirow[t]{2}{*}{ Landfill } & \multicolumn{2}{|c|}{ Recovery rate $(\%)$} \\
\hline & All activities ${ }^{\mathrm{b}}$ & $\begin{array}{l}\text { Building } \\
\text { activities }\end{array}$ & All activities ${ }^{b}$ & $\begin{array}{l}\text { Building } \\
\text { activities }\end{array}$ & & All activities ${ }^{\mathrm{b}}$ & $\begin{array}{l}\text { Building } \\
\text { activities }\end{array}$ \\
\hline 2014 & n.d. & n.d. & n.d. & n.d. & n.d. & n.d. & $55-75$ \\
\hline 2013 & 814 & 747 & 603 & 591 & 210 & 74 & 79 \\
\hline 2012 & 840 & 772 & 631 & i.b. $^{\mathrm{d}}$ & 209 & 75 & i.b. $^{\mathrm{d}}$ \\
\hline 2011 & 710 & 664 & 602 & 561 & 80 & 85 & 84 \\
\hline
\end{tabular}

a Recovery includes material recycling and backfilling

b All activities = C\&M waste from all sources (building activities, households, industry etc.)

c Building activities $=\mathrm{C} \& \mathrm{M}$ waste generated only from building activity (construction, rehabilitation and demolition)

d n.d. not determined

In 2011-2013, the total generated volumes were in the range of 710 000-840 000 tonnes, including C\&M waste from building activities, household, industry etc. (Table 3 ). If only the building activities are considered, slightly lower volumes were reported. The recovery rate for $\mathrm{C} \& \mathrm{M}$ waste generated only from building activities was $79-84 \%$ (Table 3). It is important to mention that backfilling was the most frequent type of recovery. Out of the total recycled volume reported for 2013, around $89 \%$ was recovered in backfilling scenarios.

It is emphasised that the Norwegian statistics did not include volumes from the civil engineering sector (e.g. road construction and tunnel construction). Arrangements for such an inclusion are under development according to Statistics Norway. However, the largest C\&M waste generators, like Directorate of Public Roads, Norwegian National Rail Administration and Norwegian Water Resources and Energy Directorate, have implemented basic rules and procedures for demolition and disposal of the waste generated. Furthermore, Directorate of Public Roads requires $80 \%$ of separation at source [16], which clearly facilitates recycling. Based on the information above, the same recovery rate can be assumed for $\mathrm{C} \& \mathrm{M}$ waste in the civil engineering sector as within building activities.

In order to estimate the recovery rate in 2014, some of the largest demolition contractors in Norway were contacted. They reported that $30-50 \%$ of the C\&M waste generated was sent to disposal facilities. Hence, the remaining part (50-70\%) was recycled at the demolition site or in the nearby area. For this remaining part, a recovery rate of $60-80 \%$ was achieved and the residues (largely fines) were landfilled. Based on this it seems fair to assume that $40 \%$ of the $\mathrm{C} \& \mathrm{M}$ waste generated was sent to disposal facility. The recovery rate at the disposal facility is difficult to assess precisely. However, a number of disposal facilities have a recovery rate in the range of $50-70 \%$, which gives a total recovery rate of 55-75\%.

Although the estimations above were made for the year 2014, the demolition contractors and the disposal facilities reported that the recovery rates were typical for the latest 3-4 years. Thus, this indicates that the recovery rate estimated by data from the demolition contractors was somewhat lower than the level calculated from the official statistics, as shown in Table 3.

\section{Recovery of Track Ballast}

Recovered track ballast is potentially a large material flow, but data are very limited for the Nordic countries since track ballast is not included in the waste statistics. A large fraction of the track ballast is re-used in an in situ ballast cleaning process using rail-mounted machines, where a residual fine grained fraction not fulfilling the technical requirements for track ballast is removed. Waste resulting from demolition or excavation of rail tracks is often re-used after appropriate upgrading. It can also be crushed to desired particle size and recycled in different applications. Recovery operations studied include:

- Re-use as track ballast.

- Recycling as aggregate in asphalt production or unbound applications.

- Backfilling.

Re-use of track ballast in situ or on site will result in the shortest transport distances. All other recovery alternatives for track ballast will result in transport of the material. There is also a remaining aggregate fraction, which cannot be re-used or recycled due to unsuitability in particle size, physical/mechanical properties or content of contaminants and thus may need to be treated or landfilled.

Railway operations are associated with the emission of inorganic (mainly metals) and organic substances into the environment, e.g. oils, PAH, creosote and pesticides. The release and spread of pollutants from track ballast to the subgrade and to the underlying subsoil will depend on the nature of the pollutants. The level of pollution may vary for different parts of the tracks, e.g. close to stations and areas 
for maintenance of trains as compared to free stretches. There may also be a difference depending of the age of trains used. Furthermore, the period of time since the last ballast cleaning was conducted may have an influence on the level of pollution to be found. Data on total content and leaching, given in Swedish and Norwegian surveys, indicate that a number of metals could exceed risk based guideline values, although carcinogenic PAH seems to represent the largest pollution problem for the samples analysed [17-19].

Overall it can be said that recovery operations that ensure re-use of track ballast directly on site or nearby are favourable as emissions from quarrying and transport of virgin materials can be avoided. Furthermore, it can be assumed that pollutants in track ballast are accumulated in the fine fraction $[19,20]$. For that reason, any recovery operation that $(a)$ ensures efficient cleaning and removal of the fine fraction prior to re-use of material or $(b)$ avoids or reduces contact to water and hence emission to soil and groundwater/surface water, should be preferred.

In situ ballast cleaning will remove pollutants from the railway embankment and improve the environmental conditions. Moreover, if quality criteria for the re-use or recycling of the fine fraction generated in track ballast cleaning were derived from risk assessment and applied on recovery activities, they presumably could prevent unacceptable contamination of soil, ground water and surface water resulting from recovery activities. If this is not the case, there may be a risk of spreading pollution if track ballast is recovered, e.g. in backfilling where environmental or health risk will depend on the future land use. A database on the environmental quality (contamination) of railway embankments and track ballast is now being launched by the Swedish Transport Administration. ${ }^{4}$

\section{Recovery of Gypsum-Based Construction Materials}

Gypsum-based waste is a small flow (Table 1) and there are large differences in recycling practises in the EU Member States [4]. Examples of recovery operations include:

- Recycling to produce gypsum powder for use in the manufacture of plasterboard and stucco.

- Recycling as a raw material in the cement production.

- Recycling as a nutrient and structural material in compost/agriculture soil treatment.

Natural gypsum can be substituted by FGD (flue gas desulphurisation) gypsum from coal-fired power stations and recycled $C \& D$ gypsum. This substitution reduces the

\footnotetext{
${ }^{4}$ Personal communication with Niclas Löwegren at Swedish Transport Administration, February 2016.
}

impacts on land-use and biodiversity associated with extraction of natural gypsum. Furthermore, there are potential energy and pollution savings due to shorter transport distances. The net benefits are assumed to be higher if the recycled gypsum replaces the FGD gypsum, since higher energy consumption is associated to the manufacturing of plasterboards from synthetic gypsum due to its higher moisture content [21].

Data on pollution content of, and release from, gypsumbased material are very sparse. However, the release of sulphate is generally considered the major problem in relation to contamination of groundwater and surface water. For the selected recovery operations, dust emissions may occur during demolition and transport.

With respect to the production of new plasterboards, there may be a risk of substances accumulating in the production chain, as gypsum is recycled repeatedly. When recycling gypsum-based materials as compost/soil impro$v e r$, there is a risk that substances are released to soil and groundwater.

The results of a recent Danish LCA for handling and treatment of gypsum waste, concluded that the production of new plasterboards and the use of gypsum in the production of cement are favourable as compared to the use of gypsum waste in compost [22]. The study also concluded that the environmental impacts of collection and transport, as well as use of residues from the waste gypsum, have a significant impact on the results. This means that sitespecific conditions and transport distances may be crucial for the assessment. The sensitivity analysis carried out, as part of the Danish study, showed that alternatives for substitution of natural gypsum are very important, e.g. gypsum from Spain, Germany or from power plants.

\section{Recovery of Wood Waste}

In 2012, about 0.8 million tonnes of non-hazardous wood waste from construction were generated in Denmark, Finland, Norway and Sweden (Table 1). In addition, there might be wood waste included in the reported amount of mixed waste from construction, which was about 0.8 million tonnes [4]. The wood waste (that is reported as wood waste) from the construction sector is mainly incinerated with energy recovery in Sweden, Norway and Denmark, but in Finland, the wood waste from construction may go to incineration without energy recovery. However, the methods and the basis for statistics differ substantially. Consequently, the Eurostat database is not adequate to following up the WFD target of $70 \%$ recovery. Better information about waste flows from "cradle to grave" is required.

Wood waste from C\&D activities may be divided into construction wood waste (pre-consumer recycling) and 
demolition wood waste (post-consumer recycling). Construction wood waste may be handled so that contamination and weather exposure is avoided. If so, a pure wood fraction for potential use can be sorted out using a rather simple sorting process. The first target for material recovery should therefore be the wood waste from construction sites. This fraction will probably also be less contaminated with wood suffering from biological attack (e.g. mould).

The LCA performed in the study was limited to global warming impact and describes therefore the carbon footprint. The underlying LCA inventory used two system approaches:

- The book keeping approach, also known as attributional LCA which is very robust and only includes direct consequences.

- Consequential LCA covering a complex system including indirect effects such as the substitution of margin products.

The study defined two wood-based secondary products as interesting alternatives to be produced from C\&D wood waste, namely a particle board and a wooden insulation product. These secondary products are assumed to substitute gypsum board and mineral wool in the consequential LCA.

The attributional LCA gives an environmental performance for the product, which is directly applicable for comparative purpose, i.e. for alternatives fulfilling the same function. An attributional LCA is applicable for products, but does not consider indirect consequences such as secondary effects on the fuel market. The major part of the Swedish C\&D wood waste is currently used as fuel in district heating plants and a changed use will therefore affect the marginal fuel in the supplied mix [4]. The most likely marginal fuel in the base scenario, in an expanding fuel market relevant for district heating plants, is assumed to be forestry slash (bio-fuel). For a sensitivity analysis, it is assumed that the marginal fuel is a refused derived fuel (RDF) generic waste fraction that generates $20 \mathrm{~g} \mathrm{CO}_{2} / \mathrm{MJ}$ [4]. Further description of the analysis is given in [4] and [23].

The result when performing a consequential LCA is typically dependent on which marginal fuel that is selected, meaning that this analysis describes "what happens if". In this case, when the marginal fuel is an RDF generic waste, the energy recovery of $C \& D$ wood waste will be more profitable than producing particle boards (green bar compared to yellow bar in the left part of Fig. 2b). However, in the case of material recycling to produce a wooden insulation product, the material recycling route will be the most profitable alternative (green bar compared to yellow bar in the right part of Fig. 2b).

If fossil fuel like oil or coal would be the marginal fuel, this would support the energy recovery route in both cases.
In the very short run, this assessment indicates that energy recovery is the overall preferable route, as long as a fossil fuel is the marginal fuel. If the marginal fuel is a waste fraction containing about $1 / 4$ of material with a fossil origin, the most preferable recycling route depends on what substitute is analysed. It should be noticed that current waste includes about 40 to $50 \%$ of fossil materials, which if used as fuel would change the result in Fig. 2 so that material recycling and the wood bats in this case is not the preferable route.

In conclusion, according to an attributional LCA (i.e. when only direct impacts are accounted for), the use of C\&D wood waste for manufacturing of particle board and insulation bats and then substituting the more commonly used gypsum board and mineral wool, will result in environmental benefits. According to a consequential LCA, a marginal fuel has to be defined and the environmental consequence will depend on that fuel. This marginal fuel will replace the $C \& D$ wood waste currently used as fuel in district heating plants. The two extreme alternatives are that the marginal fuel is either any fossil fuel or a (virgin) bio-based fuel. A tipping point occurs when the marginal fuel consists of about $1 / 4$ of fossil resources [23]. If the proportion is greater than $1 / 4$, the consequential LCA supports that wood should be used for energy recovery. The current situation is that about $50 \%$ of the energy mix in the district heating is of fossil origin [24, 25], and this situation will be about the same in 2030 according to the long-time energy prognosis for Sweden [26]. Moreover, in the long run when the district heating probably will be almost fossil free and biomass is the marginal fuel, the material recycling route has the potential to be the better alternative. It is also technically possible to increase the use of bio-based fuels in the future manufacturing of stone wool and thereby replace the coal used. Such development will generate an improved profile for stone wool, but is not accounted for here.

\section{Mass Flow or Carbon Footprint?}

The present recovery target for $C \& D$ waste is based on mass flow, meaning that mineral waste types will be most significant for reaching the target. An alternative approach is to give priority to waste types with high environmental impact by putting more weight to them in the calculation method for Member States implementation reports. One possibility for comparing environmental impact of waste types is to take into account environmental savings in terms of carbon footprint when they are recovered.

This approach can be illustrated for the waste types in Table 1 by displaying their mass flow together with the potential environmental savings when they are recovered (Fig. 3). It is then obvious how the importance of different 


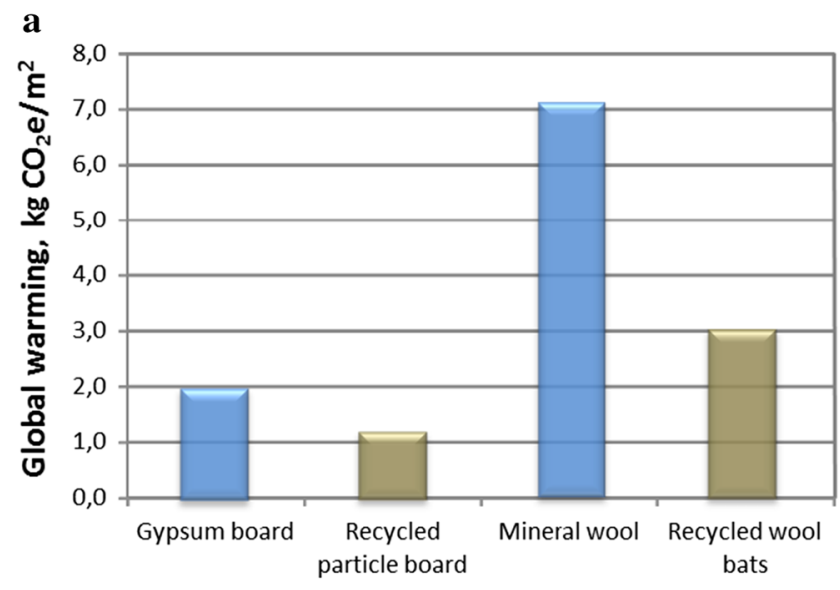

Fig. 2 Contribution to global warming from material recovery of C\&D wood waste according to LCA results. a Attributional LCA: Production of $1 \mathrm{~m}^{2}$ "traditional" board or insulation bats (blue bars) and $1 \mathrm{~m}^{2}$ particle board and insulation bats made of recovered C\&D wood waste (brown bars), b Consequential LCA: Material recovery

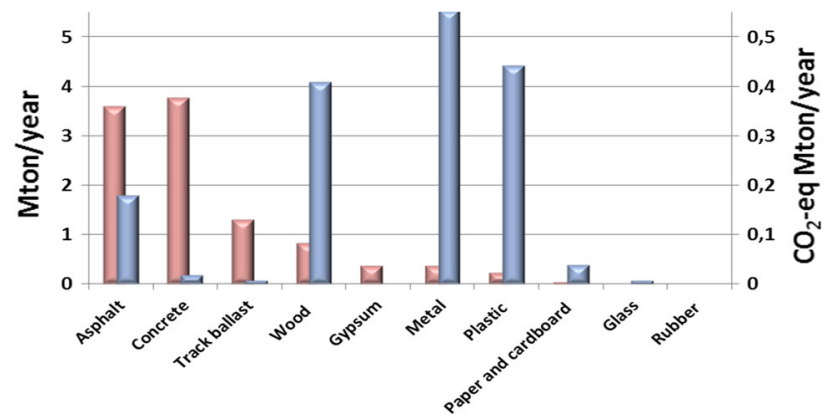

Fig. 3 Yearly waste mass flow (pink bars) and corresponding potential environmental savings (blue bars) that can be achieved with material recovery. Mass flow data are presented in Table 1. Environmental savings, with regard to climate impact, have been approximated by means of carbon footprint impact factors presented in Table 4. (Color figure online)

waste types changes, e.g. recycling of heavy mineral wastes such as concrete and track ballast provides low climate gain, while wood, metal and plastic become more important (Fig. 3).

\section{Proposals for Improving the Current Waste and Recycling Data}

Uncertainties of the current waste and recycling statistics and the lack of data on material properties were challenging. It was found that assessments of sustainable use of resources and environmental impact were not possible to conduct based on the current European statistical data. Several C\&D wastes represent premium materials with a b

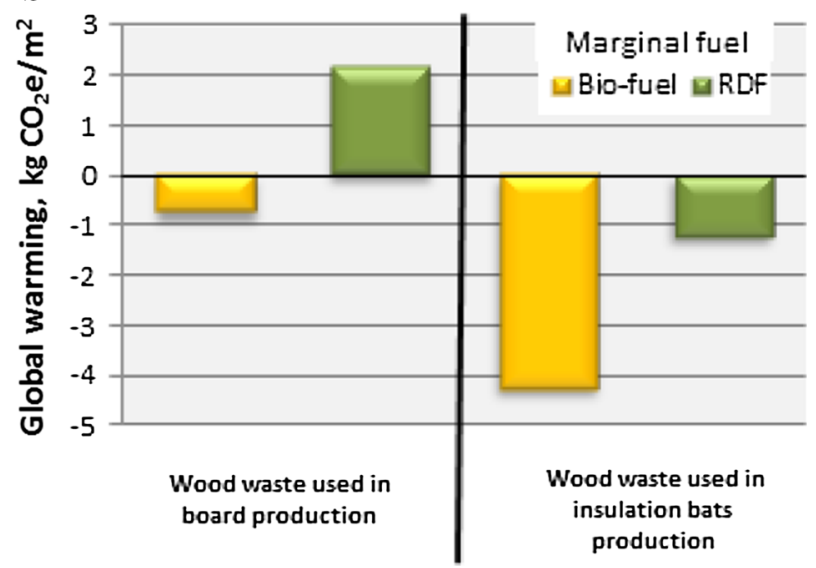

of C\&D wood waste instead of energy recovery in district heating, with consideration given to the marginal fuel. Yellow bars-bio-fuel replaces the C\&D wood waste. Green bars-a refused derived fuel (RDF) replaces $\mathrm{C} \& \mathrm{D}$ wood waste. (Color figure online)

high-grade potential for re-use or recycling. However, in the data reports, high-grade materials are often mixed with low-grade wastes (e.g. tiles, bricks, gypsum and floorings are mixed in the same waste container).

Regarding wood waste, the Eurostat waste data do not provide a structure and a level of sufficient detail to follow up the $70 \%$ target. Better information about the waste flows from cradle to grave is necessary. In particular, the following issues regarding Eurostat wood waste were found to be important to address:

- The data do not distinguish between pure wood and "treated" (painted) wood.

- In the reported amount of mixed waste from construction, wood waste is most likely included.

- The data do not show whether the wood waste from construction is re-used or recycled.

Reliable information of this type was also found to be absent for re-use and recycling of asphalt, concrete, bricks, track ballast and gypsum. For asphalt, several RA generation and recycling routes are of importance when assessing the environmental benefits, contamination content and emission of contaminants. Detailed information on these routes is required for a comprehensive assessment.

\section{Alternative Data Sources}

In some cases, national data sources can provide more useful information than the Eurostat data. In the new Danish waste registration system, it will be possible to trace wood waste. In Norway, it is mandatory to report waste handling (generation, source segregation rate and 
Table 4 Approximated carbon footprint impact factors, used in Fig. 3

\begin{tabular}{|c|c|c|c|c|}
\hline & \multicolumn{2}{|c|}{ Impact factor } & \multirow{2}{*}{$\frac{\text { Material recovery }}{\text { Recycled as new asphalt }}$} & \multirow{2}{*}{$\begin{array}{l}\text { Reference } \\
{[32]}\end{array}$} \\
\hline Asphalt & 50 & $\mathrm{~kg} \mathrm{CO}$-eq/t & & \\
\hline Concrete & 4 & $\mathrm{~kg} \mathrm{CO}$-eq/t & Recycled as crushed aggregates & {$[32]$} \\
\hline Track ballast & 4 & $\mathrm{~kg} \mathrm{CO}$-eq/t & Recycled as aggregates & {$[32]$} \\
\hline Wood & 500 & $\mathrm{~kg} \mathrm{CO}{ }_{2}$-eq $/ \mathrm{kg}$ & Recycled as wood particle board & {$[4]$} \\
\hline Gypsum & 4 & $\mathrm{~kg} \mathrm{CO}$-eq/kg & $\begin{array}{l}\text { Replacing virgin gypsum in } \\
\text { gypsum board }\end{array}$ & {$[4]$} \\
\hline Metal & 1500 & $\mathrm{~kg} \mathrm{CO}$-eq/t & Recycled as metal & {$[32]$} \\
\hline Plastic & 2000 & $\mathrm{~kg} \mathrm{CO}$-eq/t & Recycled as plastic & {$[32]$} \\
\hline $\begin{array}{l}\text { Paper and } \\
\text { cardboard }\end{array}$ & 1000 & $\mathrm{~kg} \mathrm{CO}$-eq/t & Recycled as cardboard & \\
\hline Glass & 500 & $\mathrm{~kg} \mathrm{CO}$-eq/t & Recycled as glass & \\
\hline Rubber & 500 & $\mathrm{~kg} \mathrm{CO} \mathrm{CO}_{2}-\mathrm{eq} / \mathrm{t}$ & Recycled as rubber & \\
\hline
\end{tabular}

disposal option used, recovery rate etc.) from construction, rehabilitation and demolition activities to the municipality [27]. The Norwegian C\&D waste statistics are partly based on these reports. However, since they come from a relatively small number of municipalities, an increased collection of waste handling reports may form a more statistically sound basis for following the flows of waste from the generation to the treatment.

In Sweden, there is no regular and complete collection of $\mathrm{C} \& \mathrm{D}$ waste statistics. Amendments of the legislation have recently been implemented to improve the situation and further adjustments are under consideration. The idea is to achieve clearer, more specified and standardized requirements and to use data on material flows from waste treatment plants [28]. However, data on the waste quality will still be missing. To obtain such data it is necessary to cooperate with the supplier associations.

Large flows of asphalt, track ballast and concrete are traditionally not reported as waste handling, and the practice of re-use techniques in situ, e.g. for asphalt and track ballast, further creates demarcation problems in relation to the waste and waste handling definitions in the current legislation. These material flows are significant and will have a huge impact on the fulfilment of a weight-based target. If the flows are included in the following-up of the $70 \%$ target, data have to be collected from industry organizations, clients or contractors. For asphalt and track ballast, this would be possible since major governmental clients and a limited number of contractors dominate the markets. In some cases, there is already a certain collection of statistical data by industry organizations.

\section{European Standardisation and CE Marking}

Available data on environmental quality are uncertain due to the use of diverse and poorly documented (non-standardised) sampling, sample treatment, emission measurements and content analysis methods. A standardised data collection regarding the content and leaching of contaminants would enable better assessment of potential environmental risks than currently possible. Within the European standardisation work for construction products (CEN/TC $351^{5}$ ), test methods for determination of content and emissions of dangerous substances have been developed. It is important that these methods are implemented in the product standards and that Member States include requirements to declare these properties in their regulation and approval systems.

Quality requirements for recycled C\&D waste when used as construction material are covered by some of the harmonised European construction product standards (e.g. for aggregates and asphalt). Discussion is needed on how to address recycling aspects in CE marking, both regarding savings of natural materials and release of specific substances to soil and water. For waste related construction products, the information of release should be reported as actual measured values (and not as classes indicating values below a threshold), thus providing an additional source of relevant data. Numerical data would enable further use as input data in environmental product declarations (EPD) and risk assessment. In the context of circular economy, it is believed that this form of "direct" data would be needed for all construction products; either they are made by waste derived materials or by natural raw materials.

\section{Proposals for Improving the Waste Recovery Target}

\section{Wastes Covered and the Calculation Method for Reporting Progress}

The studied waste types represent large material flows with good prospects for re-use and recycling in new

\footnotetext{
${ }^{5}$ CEN/TC 351 - Construction Products-Assessment of release of dangerous substances.
} 
constructions, in addition to other recovery routes. However, the study found that addressing all waste generation and waste recycling flows in one single target does not necessarily promote a sustainable waste recovery.

The current target is very sensitive to interpretations of what is considered as waste recycling and to uncertainties in the current statistics. Furthermore, the current target is weight-based and therefore mineral wastes will have the largest impact while the largest environmental benefits might be on other waste types.

Based on the findings, it is suggested that the general target of $70 \%$ should be transformed into material specific recovery targets. These should be set to reflect the different waste types' potential benefits when they are recycled. The targets could be set both on a European and on a national level. As an example, high recovery targets $(90 \%)$ could be set for waste types with well-functioning recovery routes within the construction sector, e.g. asphalt and crushed concrete. For waste types where presence of contaminants might be a major problem, e.g. the fine fraction resulting from recycling of track ballast, a lower recovery rate is needed. An ambitious recovery rate is also recommended for $C \& D$ waste with high relative environmental impact and well-functioning recycling outside the construction sector, such as metal, paper and plastics.

\section{Recovery Routes Covered}

The current target does not distinguish between the recovery operations, meaning that resource efficient and environmentally safe recovery cannot be given priority. As an example, backfilling is currently considered equal to other recovery operations when reporting compliance with the target. This may lead to an increased risk of "downcycling", which means that the waste is not used in the most optimal way. Besides, renewed recovery in the future is more unlikely for backfilled materials. Furthermore, environmental risks will depend on the land use scenario of the backfilled area, which may change without prior assessment.

The re-use or recycling into new constructions is often favourable due to environmental benefits (e.g. savings of virgin resources or minimised transport) even if the recovered materials are contaminated compared to virgin raw materials. The constructions often provide means of protection against release and exposure to contaminants. Future management of waste during the demolition or maintenance of constructions could also ensure that future recovery can be sustained.

Thus, we recommend that the recovery target should distinguish between different recovery operations. Backfilling should be regulated by more stringent environmental quality criteria than other recovery operations. The use of quality criteria derived from risk assessment, may prevent unacceptable contamination of soil, groundwater and surface water because of backfilling activities. Furthermore, it was shown that the use of recycled concrete waste in the road sub-base imposed less leaching of $\mathrm{Cr}, \mathrm{Zn}$ and $\mathrm{SO}_{4}{ }^{2-}$ over a period of 100 years compared to the use as drainage material in a landfill (Table 2).

National targets should be set up so that the most effective re-use and recycling routes are promoted and those posing the biggest environmental risk are avoided. This could be done in combination with management guidelines, environmental quality criteria and cost evaluations. As an example, recycling of asphalt into new asphalt should be promoted and assigned a higher recovery target $(>70 \%)$ while other, less beneficial, asphalt recycling routes (e.g. use as unbound aggregates) be avoided or given lower priority. For wood waste, the situation is more unclear due to lack of well-functioning recycling techniques and because energy recovery could still be beneficial if fossil fuel is substituted. At short sight, a low recovery target for wood waste is therefore recommended from an environmental point of view.

\section{Conclusions}

The EU recovery target for C\&D waste does not ensure a sustainable waste recovery in its present form since:

- It is very sensitive to interpretations of what is considered as waste and waste recovery. This fact is significant since the WFD definitions of waste recovery actions such as re-use or recycling, are mainly aimed at the building construction field and does not fit well with materials recovered within other construction fields. As an example, asphalt and track ballast, which represent large material flows with a high re-use or recycling rate, are generally not included in the waste statistics in the Nordic countries and this will highly influence the interpretation of attaining the target.

- It favours recycling of waste types with large mass flows. The result is that mineral wastes will have the largest impact while the largest environmental benefits might be on other waste types.

- It does not favour the most sustainable recovery operations. Above all, it does not distinguish between backfilling and other more resource efficient recovery operations. Since backfilling is a recovery option that generally results in both low benefits and future environmental risks, this increases the risk for "downcycling", which means that the waste is not recovered in the most optimal way. In addition, energy recovery of $\mathrm{C} \& \mathrm{D}$ wood waste is not included in the recovery 
target even though this alternative can be regarded as equal to other recovery operations in the near future. This conclusion based on LCA is valid for all material combustion with energy recovery.

Based on the conclusions the following recommendations are given:

- Transform the general weight-based recovery target into waste specific targets. This would favour recycling of C\&D waste in general and not only for high weight materials.

- Rank the recovery operations in the calculation method for reporting progress. Backfilling should not be regarded as equal to other operations for recovery.

To achieve a sustainable recovery, improved knowledge on C\&D waste generation and handling, as well as on content and emissions of dangerous substances, is required.

Acknowledgments The authors express their gratitude to the funders of this project: the Nordic Council of Ministers, the Swedish Geotechnical Institute, Ångpanneföreningen's Foundation for Research and Development, the Foundation for the Swedish Environmental Research Institute (SIVL), the Swedish Environmental Protection Agency, Norwegian Environment Agency and the Ministry of the Environment Finland.

\section{Compliance with Ethical Standards}

Conflict of interest The authors declare that they have no conflict of interest.

Open Access This article is distributed under the terms of the Creative Commons Attribution 4.0 International License (http://crea tivecommons.org/licenses/by/4.0/), which permits unrestricted use, distribution, and reproduction in any medium, provided you give appropriate credit to the original author(s) and the source, provide a link to the Creative Commons license, and indicate if changes were made.

\section{References}

1. Directive 2008/98/EC of the European Parliament and of the Council of 19 November 2008 on waste and repealing certain Directives. OJ L 312, 22.11.2008

2. 2011/753/EU: Commission Decision of 18 November 2011 establishing rules and calculation methods for verifying compliance with the targets set in Article 11(2) of Directive 2008/98/EC of the European Parliament and of the Council (notified under document C(2011) 8165). OJ L 310, 25.11.2011

3. 2014/955/EU: Commission Decision of 18 December 2014 amending Decision 2000/532/EC on the list of waste pursuant to Directive 2008/98/EC of the European Parliament and of the Council text with EEA relevance pursuant to Article 1(4) of Council directive 91/689/EEC on hazardous waste. OJ L 370/pp. 44-86, 30.12.2014

4. Arm, M., Wik, O., Engelsen, C.J., Erlandsson, M., Sundqvist, J-O., Oberender, A., Hjelmar, O., Wahlström, M.: ENCORTCDW-Evaluation of the European recovery target for construction and demolition waste. Nordic Council of Ministers, Nordic Working Papers 2014:916, (2014). Accessed 7 July 2016

5. Eurostat: Eurostat's database. Link. Accessed 7 July 2016

6. Wahlström, M., Laine-Ylijoki, J., Järnström, H., Kaartinen, T., Erlandsson, M., Palm Cousins, A., Wik, O., Suer, P., Oberender, A., Hjelmar, O., Birgisdottir, H., Butera, S., Fruergaard Astrup, T., Jørgensen, A.: Environmentally sustainable construction products and materials - assessment of release and emissions. Nordic innovation report 2014:03, (2014) http://www.nordi cinnovation.org/Global/_Publications/Reports/2014/Environmen tally $\% 20$ Sustainable $\% 20$ Construction $\% 20$ Products $\% 20$ and $\% 20$ Mate rials_Final_report.pdf Accessed 7 July 2016

7. Barry, K., Daniel, J.S., Foxlow, J., Gray, K.: An evaluation of reclaimed asphalt shingles in hot mix asphalt by varying sources and quantity of reclaimed asphalt shingles. Road Mater. Pavement Des. 15(2), 259-271 (2014)

8. EAPA: Statistics for the years 2011-2014. European Asphalt Pavement Association. (2012, 2013, 2015 and 2016) http://www. eapa.org/promo.php?c=174

9. KFA. Reclaimed asphalt pavement (RAP) in Norway. Kontrollordningen For Asfaltgjenvinning (The Info Center for Recycling of Asphalt), Hövik, Norway, (2012) http://www.asfaltgjenvin ning.no/resources/files/rap/RECLAIMED_Asphalt_Pavements.pdf. Accessed 8 July 2016

10. Hjelmar, O., Hansen, E.Aa., Hyks, J., Hougaard, T.: Spredning af problematiske stoffer ved materialnyttiggørelse af asfalt til vejbygningsforhold (Release and migration of problematic substances from use of recycled crushed asphalt in road construction), Miljøprojekt nr. 1731, Danish Environmental Protection Agency, (in Danish, English summary) (2015)

11. Hjelmar, O., Hyks, J., Hansen, E. Aa., Jensen, J.K.: Recycling of crushed asphalt for use in road construction: Assessment of the potential impact on groundwater and surface water. Proceedings Sardinia 2015, Fifteenth International Waste Management and Landfill Symposium, S. Margherita di Pula, Cagliari, Italy, 5-9 October 2015

12. Re-Road: Life cycle assessment of reclaimed asphalt. Re-roadend of life strategies of asphalt pavements, deliverable 3.4, (2012). Accessed 7 July 2016

13. STA: Hantering av tjärhaltiga beläggningar (Handling of tar contaminated asphalt pavements). Swedish Transport Administration, Publ 2004:90, (2004) (in Swedish). Accessed 7 July 2016

14. Uggerud, H.Th.: Målinger av støv fra håndtering av resirkulert tilslag (Measurements of dust emissions from handling of recycled aggregates), NILU OR 9/2002, ISBN 82-425-1340-6 (2002) (in Norwegian)

15. Flyer "REBRICK-from demolition waste to old bricks ready for reuse" http://www.gamlemursten.eu/files/7713/3948/9356/Rebrick_ folder_2.pdf

16. Norwegian Directorate of public roads: Guideline for waste management, Handbook R765, (2014) ISBN: 978-82-7207-654-1 (in Norwegian)

17. Backman, E., Löwegren, N.: Diffusa föroreningar i banvallar (Diffuse pollutants in railway embankments). Swedish Transport Administration, Rapport Bansystem 04-03, Diarienr B 03-1733/ IN60, (2004) (in Swedish)

18. Haugland, T., Eggen, O.A.: Innhold av miljøgifter i ballastpukk (Content of environmental pollutants in track ballast). Geological Survey of Norway, Report 2007.011, (2007) (in Norwegian)

19. Wik, O., Toomväli, C.: Bedömning av återvunna sorterade ballastreningsmassor (Assessment of recycled track ballast). Swedish Geotechnical Institute, Dnr 7.1-1510-0629, 2016-01-20, (2016) (in Swedish)

20. Gustafsson, M., Blomqvist, G., Håkansson, K., Lindeberg, J., Nilsson-Påledal, S.: Järnvägens föroreningar-källor, spridning och åtgärder. En litteraturstudie (Railway pollution-sources, 
dispersion and measures. A literature review). VTI report 602, The Swedish National Road and Transport Research Institute (VTI), (2007) (in Swedish, English summary)

21. Monier, V., Hestin, M., Trarieux, M., Mimid, S., Domröse, L., Van Acoleyen, M., Hjerp, P., Mudgal, S.: Study in the management of construction and demolition waste in the EU. European Commission (DG Environment), contract 07.0307/2009/540863/ SER/G2, Final report, (2011)

22. Møller, J., Butera, S., Sanchez, V.M., Christensen, T.H., Kromann, M., Willumsen, E.: Livscyklusvurdering og samfundsøko nomisk vurdering af forskellige alternativer for håndtering $\mathrm{og}$ behandling af gipsaffald (Life cycle and socio-economic evalua tion of alternatives for gypsum waste handling and treatment), Danish EPA, Miljøprojekt no 1410, (2012) (in Danish). Accessed 7 July 2016

23. Erlandsson, M., Sundqvist, J-O.: Environmental consequences of different recycling alternatives for wood waste. IVL Swedish Environmental Research Institute, report B 2182, (2014)

24. Blomqvist, E. W., Jones, F.: Bestämning av andel fossilt kol i avfall som förbränns i Sverige. (Calculation of the proportion of fossil carbon in waste incinerated in Sweden.) Avfall Sverige. Report No U2012:02, (2012) (in Swedish)

25. Profu: Analys av den fossila andelen av norskt avfall med hänsyn till energiinnehåll (Analysis of the fossil share of Norwegian waste in view of the energy content), Profu i Göteborg AB, project report 2006-05-05, (2006) (in Swedish)
26. SEA: Scenarier över Sveriges energisystem-2014 års långsiktiga scenarier, ett underlag till klimatrapporteringen (Scenarios of the Swedish energy system-longterm scenarios of 2014, basis for the climatic report), Swedish Energy Agency, report No ER 2014:19, (2014) (in Swedish) Accessed 7 July 2016

27. Norwegian Ministry of Local Government and Modernisation: Byggteknisk forskrift (TEK10) (Regulations on technical requirements for building works), FOR-2010-03-26-489, (2010). Accessed 7 July 2016

28. SEPA: Förbättrad avfallsstatistik och spårbarhetssystem (Improved waste statistics and system for traceability), Swedish Environmental Protection Agency, interim report to the government, (2015) (in Swedish). Accessed 7 July 2016

29. Union Internationale Des Chemins De Fer (UIC): Statistics 2015. http://www.uic.org/statistics\#documents. Accessed 7 July 2016

30. Eurostat: Eurostat's database. http://ec.europa.eu/eurostat/data/ database. Accessed 7 July 2016

31. Resource efficient use of mixed wastes-construction and demolition waste management in FINLAND V3-December 2015. http://ec.europa.eu/environment/waste/studies/deliverables/ CDW_Finland_Factsheet_Final.pdf Accessed 8 July 2016

32. Klimatkalkyl (Climate impact Calculator). Swedish Transport Administration http://www.trafikverket.se/klimatkalkyl/ (in Swedish) Accessed 23 February 2016 